\title{
ORGANIZATIONAL CULTURE AND INTER-GROUP BEHAVIOUR IN GUARANTY TRUST BANK IN NIGERIA
}

\author{
Worluchem Ayodele \\ Department of management \\ University of Port Harcourt Business
}

\author{
B. Chima Onuoha \\ Department of Management \\ University of Port Harcourt
}

\author{
Best C. Eke \\ Department of management \\ University of Port Harcourt
}

Article DOI: https://doi.org/10.36713/epra5287

\begin{abstract}
The study empirically investigates organizational culture and inter-group behaviour in Guaranty trust bank in Nigeria. Primary data was used for the study and the data for analysis was gotten through questionnaire. The questionnaire was issued to the staff of Guarantee Trust Bank in Rivers State. The data was analyzed with the use of Chi-square in other to measure the discrepancies existing between the observed and expected frequency and to proof the level of significance in testing stated hypotheses. From the result of the study, it was discovered that organizational culture has significant influence on inter-group behaviour. Therefore, the study recommends that Guarantee Trust Bank should encourage new entrants to get internalize first with the bank's culture to know whether they can cope with them or not. Additionally, organizations should provide adequate motivational factors like housing allowance, car loan, holiday allowance, health allowance, etc.
\end{abstract}

\section{INTRODUCTION}

An organization refers to a collection of people, who are involved in pursuing defined objectives. It can also be referred as the second most important managerial function, that coordinates the work of employees, procures resources and combines the two, in pursuance of company's goals (Hall, 1999). The essence of organizations revolves around the development of shared meanings, beliefs, values and assumptions that guide and are reinforced by organizational behaviour. Employees are important asset to the organization. They serve as human capital to the organization. organizations make use of their employees' skills, knowledge and abilities in carrying out and fulfilling their objectives. Culture is the environment that surrounds employees at work all of the time. Culture is a powerful element that shapes employees work enjoyment, work relationships, and work processes. However, culture is something that one cannot actually see, except through its physical manifestations in work place. The culture of the organization should be developed to support continuous improvement, improve employees' style of performing their job and thus develop quality awareness. Organizational culture has influenced on inter-group behaviour as a result of the acceptable behaviours and attitudes to various jobs in the organization. organizational culture is a major determinant of an employee's efficiency and effectiveness in carrying out their jobs. That is, organizational culture is one of the major key determinants of how employees perform or behaves in his job.

Academic interest in organizational culture is evidenced by the level of attention it has received over the last few decades. The relationship between organizational culture and inter-group behaviour has been the subject of abundant research in several fields. While this topic is rich in studies, many researchers concur on the fact that there is no agreement on the precise nature of the relationship between organizational culture and inter-group behaviour. Despite the plethora of studies on organizational culture in the last few decades, there is no widely accepted causal relationship between organizational culture and inter-group behaviour. The empirical evidences emerging from various studies about the 
effect of organizational culture on inter-group behaviour have so far yielded mixed results that are inconclusive and contradictory. Because of these contradictory results, the question of whether organizational culture improves or worsens inter-group behaviour is still worthy of further research such as the one being undertaken in this study. In addition, despite the existence of these studies, very little attention has been given to developing countries. This means that the impact of organizational culture on employee's work behaviour has not received adequate research attention in Nigeria. Thus, there is a major gap in the relevant literature in Nigeria, which has to be covered by research. This research attempts to fill this gap by studying the situation of the Nigerian Banking Industry and providing more empirical evidence on the effects of organizational culture on inter-group behaviour in Guarantee Trust Bank Plc.

\section{Aim and Objectives of the Study}

The explicit objectives of this study are:

(i) to ascertain if organizational culture influence inter-group work behaviour. to find out if organizational culture affects organizational productivity.

to disclose whether a change in organizational culture could lead to a change in inter-group work behaviour.

\section{Research Hypotheses}

Three hypotheses were also put forward. They are:

(i) organizational culture has a significant influence on inter-group work behaviour. organizational culture has a significant influence on organizational productivity.

(iii) A change in organizational culture will cause a change in inter-group work behaviour. These objectives and hypotheses guide the researcher in his study. Organizational culture is based on the history and tradition of the organization or what an organization has been identified with to be consistent in doing from time past. It is the ability of inter-group to adapt to this organization tradition and systems that will enable them perform well in the job and thus boost organizational productivity. Therefore, this study will concentrate on organizational culture as a major factor that influences inter-group behaviour.

\section{LITERATURE REVIEW Conceptual Framework of organizational Culture}

An organization's culture defines the proper way to behave within the organization. This culture consists of shared beliefs and values established by leaders and then communicated and reinforced through various methods, ultimately shaping employee perceptions, behaviors and understanding. The subject of organizational behaviour has been studied from a variety of perspectives ranging from disciplines such as anthropology and sociology, to the applied disciplines of organizational behaviour, management science, social sciences and organizational communication. The study of organizational culture has been widely accepted and explained by different scholars but there is no one definition of organizational culture that is generally accepted (Ojo, 2008). Organizational culture permeates organizational life in such a way as to influence every aspect of the organization (Hallett, 2003). Organizational culture also has effect on the productivity level of the organization in the sense that it influences employee's behaviour to work and it is the input of the employees to the organization that determines the organizational productivity level. It has been suggested that organizational culture affects such outcomes as productivity, performance, commitment, self-confidence, and ethical behaviour (Buchanan and Huczynski, 2004; Shani and Lau, 2005; and Ojo, 2009). organizational culture is one of the core determinants of every organization's success as it influences employee work behaviour.

Organizational culture is one of the metaphors used for organizational analysis (Morgan, 1997). In this metaphor, the essence of organization revolves around the development of shared meanings, beliefs, norms, values and assumptions that guide and are reinforced by organizational behaviour. organizational values are important because they have effects on important individual and organizational outcomes. Organizational values are expected to produce higher levels of productivity (Jehn, 1994; Hall, 1999), job satisfaction (Jehn 1994), and commitment (Pettinger, 2000). organizational values are also important because the fit between organizational and individual values affects important individual and organizational outcomes. Values-fit has been shown to affect application decisions (Cable and Judge, 1996; Cable and Judge, 1997; Scott, 2000a), job satisfaction (Bretz and Judge, 1994), and job tenure (Bretz and Judge, 1994; Ritchie, 2000). organizational culture has been seen as the pattern or way a given group has invented, discovered or developed in carrying out a particular task or solving a particular problem or useful and effective in learning. This pattern must have worked well enough for the group to be considered valid and therefore must be taught to new members or entrants as the correct way to perceive, think and feel in relation to those problems. organization culture is a set of values that help organizational members know that which is 
acceptable and that which is unacceptable within the organization (Ojo, 2010)

\section{How organizational Culture Develops}

The values and norms which are the basis of culture are formed through the following four ways (Finegan, 2000).

i. By Leaders in the organization, especially those who have shaped them in the past. People identify with visionary leaders how they behave and what they expect. They note what such leaders pay attention to and treat them as role models.

ii. Through Critical Incidents or Important events from which lessons are learned about desirable or undesirable behaviour.

iii. Through effective working relationship among organizations members. This establishes values and expectations.

iv. Through the organization's Environment

Culture is learned over a period of time. Where a culture has developed over long periods of time and has become firmly embedded, it may be difficult to change quickly.

\section{Dimension of organizational Culture}

Jones, Chine and Ryan (2006) in some comparative works published said that seven dimensions could be used to compare culture across organizations.

- Innovation and risk taking - willing to experiment, take risks, encourage innovation
- $\quad$ Attention to detail - paying attention to being precise vs. saying its "good enough for chopped salad"

- Outcome orientation - oriented to results vs. oriented to process

- People orientation - degree of value and respect for people. Are people considered unique talents, or is an engineer an engineer an engineer.

- Individual vs. Team orientation - are individuals most highly noted, or are collective efforts

- Aggressiveness - taking action, dealing with conflict

- $\quad$ Stability - openness to change

Deal and Kennedy (1999) also identified four key dimensions of culture:

1. Values - the beliefs that lie at the heart of the corporate culture.

2. Heroes - the people who embody values.

3. Rites and rituals - routines of interaction that have strong symbolic qualities.

4. The culture network - the informal communication system or hidden hierarchy of power in the organization.

Types of Organizational Culture

Handy (1993) identify four main types of culture to be found in organizations, which are summarized in Figure 1 below.

\begin{tabular}{|l|l|l|}
\hline \multicolumn{1}{|c|}{ Type } & \multicolumn{1}{|c|}{ Metaphor } & \multicolumn{1}{c|}{ Characteristics } \\
\hline Power Culture & A web & $\begin{array}{l}\text { Control/power emanate from the centre; very } \\
\text { political and entrepreneurial; resource power and } \\
\text { personal power predominates. This culture serves the } \\
\text { figure head and the leader. }\end{array}$ \\
\hline Role Culture & A Greek temple & $\begin{array}{l}\text { Classical structure; bureaucratic nature; roles more } \\
\text { important than the people who fill them; position } \\
\text { power predominates, and expert power tolerated. } \\
\text { This culture serves the structure. }\end{array}$ \\
\hline Task Culture & A net & $\begin{array}{l}\text { The focus is on completing the job; individuals' } \\
\text { expertise and contribution are highly valued; expert } \\
\text { power predominates, but both personal and position } \\
\text { power are important; the unifying force of the group } \\
\text { is manifested in high level of collaboration. }\end{array}$ \\
\hline
\end{tabular}




\begin{tabular}{|l|l|l|}
\hline Person culture & $\begin{array}{l}\text { A Cluster or } \\
\text { galaxy }\end{array}$ & $\begin{array}{l}\text { A loose collection of individuals - usually } \\
\text { professionals - sharing common facilities but } \\
\text { pursuing own goals separately; power is not really } \\
\text { an issue, since members are experts in their own } \\
\text { right. This type of culture serves the individual. }\end{array}$ \\
\hline
\end{tabular}

Source: Handy, 1993: Understanding Organizations. $4^{\text {th }}$ Edition, Penguin Business

Handy (1993) suggests that the culture within an organization affects the way that it operates and its members behave. One type of culture is not necessarily better than another; although one type of culture might be more appropriate than others in particular circumstances. For example, a role culture could be appropriate when the organization exists in a fairly stable environment. A role culture could have difficulty in adapting to change. In contrast, power culture or task culture are probably more effective in conditions of change. Management in an organization might take the view that to be successful; the organization must be innovative, and continually look for new markets, new and better products and improved processes. Innovation is often associated with the task culture. It can therefore be tempting for management to try to change the culture of their organization, so that it's become more task- oriented.

Cascio (2006) also outlined four types of organizational culture and termed them as Organizational Ideologies'. These are:

i. Power-oriented - competitive, responsive to personality rather than expertise ii. Peopleoriented - consensual, rejecting management control

ii. Task-oriented - with a focus on competency, dynamic

iii. Role-oriented - with a focus on legality, legitimacy and bureaucracy

\section{Concept of Behaviour}

The term employee behavior, refers to the way in which employees respond to specific circumstances or situations in the workplace. While many elements determine an individual's behavior in the workplace, employees are shaped by their culture and by the organization's culture. Behaviour is something psychologists have been trying to define for ages. Several theories have come up and each has been right in a way. But we still don't have an exact definition for human behaviour. We probably never will have one, because human beings change and each individual is different from one another. It might be possible to have a few generalizations but the truth is that each one of us does things differently. The operant conditioning model is one such model used to explain human behavior. Conditioning is a "systematic procedure through which associations and responses to specific stimuli are learned" (Hollinshead, Nicholls and Tailby, 2003). Operant conditioning is defined as "a type of learning in which the desirable or undesirable consequences of behaviour determine whether the behaviour is repeated" (Sorensen, 2002). It is also known as instrumental conditioning. The probability of an event occurring depends on its consequences. Much of the research on the operant model was done by B. F. Skinner and E.L. Thorndike. But the basic principle that governs operant conditioning is known as the law of effect. The law states that behaviours followed by desirable outcomes are more likely to recur than behaviours with unpleasant outcomes and vice versa. Rewards and punishments do affect our behaviour.Shaping is an operant conditioning procedure in which "closer and closer approximations of the desired behaviours are reinforced, as a way of eventually producing the desired behaviour" (Osland, Kold and Rubin 2001; McShane and von Glinow, 2008).

\section{METHODOLOGY}

In this section, the researcher detailed the research methodology used to achieve the purpose of the study. The survey research design was used in this study. Survey research design was chosen because the sampled elements and the variables that are being studied are simply being observed as they are without making any attempt to control or manipulate them (Ojo, 2003). The theoretical population of the study consists of the staff of guaranty trust bank Plc. in Rivers State, Nigeria. For effective coverage and lower cost, stratified sampling technique was used to select the participating respondents. The workers were stratified into junior, intermediate, and senior. Thereafter, a total of 55 employees were selected using simple random sampling method. However, only 50 out of 55 respondents returned filled questionnaire and were used for final analysis in this study. It is the believe of the researcher that the sampled elements for the study have significant understanding of the 
concepts and terminologies used in the study and contained in the questionnaire they completed. This premise was based on the educational background of the respondents in which only $8 \%$ of them have General Certificate of Education "Ordinary Level" while the remaining $92 \%$ of the respondents possessed higher educational qualification. Primary data collected through the administration of questionnaire were used for this study. The questionnaire was titled "organizational Culture and inter-group Behaviour Questionnaire" One important way of ensuring that we have used the right instrument and have taken correct measurement is that our outcome must be in consonance with two major criteria for measuring quality known as validity and reliability (Ojo, 2003). To ensure the validity and reliability of the questionnaire used for the study, even number of experts were consulted to look at the questionnaire items in relation to its ability to achieve the stated objectives of the research, level of coverage, comprehensibility, logicality and suitability for prospective respondents. Data collected from the questionnaire were analyzed, summarized, and interpreted accordingly with the aid of descriptive statistical techniques such as total score and simple percentage. Chi-square was used to measure the discrepancies existing between the observed and expected frequency and to proof the level of significance in testing stated hypotheses.

\section{TESTING OF HYPOTHESES AND DISCUSSION OF RESULTS}

In this section we shall be concerned with two things; hypotheses testing and discussion of results. There are various statistical tools that can be used for testing of hypotheses but this research work will be limited to the use of chi-square (x2) statistical tool.

\section{Hypothesis 1}

$\mathrm{H}_{0}$ Organizational culture has no significant influence on inter-group work behaviour

$\mathrm{H}_{1}$ Organizational culture has a significant influence on inter-group work behaviour

\begin{tabular}{|c|c|c|c|c|}
\hline & $\begin{array}{l}\text { Observed } \\
\text { (0) }\end{array}$ & $\begin{array}{c}\text { Expected } \\
\text { (E) }\end{array}$ & $\begin{array}{l}\text { Residual } \\
(0-E)\end{array}$ & $(\mathrm{O}-\mathrm{E})^{2}$ \\
\hline Strongly Disagree & 2 & 10.0 & -8.0 & 64.0 \\
\hline Disagree & 2 & 10.0 & -8.0 & 64.0 \\
\hline Undecided & 4 & 10.0 & -6.0 & 36.0 \\
\hline Agree & 27 & 10.0 & 17.0 & 289.0 \\
\hline Strongly Agree & 15 & 10.0 & 5.0 & 25.0 \\
\hline Total & 50 & & & \\
\hline
\end{tabular}

Test Statistics

\begin{tabular}{|c|c|}
\hline & $\begin{array}{c}\text { organizational culture influences } \\
\text { employee work behaviour }\end{array}$ \\
\hline Chi-Square(a) & 47.800 \\
Df & 4 \\
Asymp. Sig. & .000 \\
\hline
\end{tabular}

In testing the first hypothesis, the calculated $\mathrm{x} 2$ is greater than the tabulated $\mathrm{x} 2$, we therefore reject the null hypotheses (H0) and accept the alternative hypotheses $(\mathrm{H} 1)$. This indicates that organizational culture has a significant influence on inter-group work behaviour. 
Dependent Variable: Organizational Productivity

Tests of Between-Subjects Effects

\begin{tabular}{|c|c|c|c|c|c|c|}
\hline Source & $\begin{array}{c}\text { Type III Sum of } \\
\text { Squares }\end{array}$ & df & Mean Square & F & Sig. & $\begin{array}{c}\text { Partial Eta } \\
\text { Squared }\end{array}$ \\
\hline Corrected Model & $5.898^{\mathrm{a}}$ & 6 & 3.650 & 8.399 & .000 & .167 \\
Intercept & 6.449 & 1 & 7.449 & 22.047 & .000 & .766 \\
Organizational & 5.210 & 3 & 1.737 & 8.843 & .000 & .096 \\
Productivity & .165 & 1 & .165 & .840 & .360 & .003 \\
\hline Place of Residence & 2.284 & 2 & 1.142 & 5.815 & .003 & .044 \\
Productivity* & 49.296 & 47 & .196 & & & \\
Residence & 534.000 & 49 & & & & \\
Error & 59.194 & 50 & & & & \\
\hline Total & & & & & \\
\hline
\end{tabular}

a. R Squared $=.167$ (Adjusted R Squared $=.147$ )

From the above result, one can observed that there is a statistical significant difference on the organization productivity for the independent residence as 0.000 is less than 0.05 . The corresponding partial eta squared computed to be 0.096 implies that 9.6 per cent of variations in the organizational productivity is attributable to the location of the bank branch. Though, it is not significant in explaining variations in organizational productivity of the organization under investigation. Put differently, the local or residence (urban or rural) is not a key determinant of organizational productivity. The interaction effect is given by (Productivity times residence). This is significant as well and the effect size is 4.4 per cent given by the Partial Eta Squared result.

\section{CONCLUSION}

In this study, the researcher tried to look at the analysis of the influence of organizational culture on inter-group behaviour with evidence drawn from Guaranty Trust Bank in Rivers State, Nigeria. Questionnaires were administered to respondents who are employees at Guaranty Trust Bank. To find out their opinions and views about organizational culture and its influence on Guarantee Trust Bank behaviour. The main focus of this study is to make recommendations that will help managements to create, maintain, sustain and otherwise modify culture in a way that it will help improve inter-group work behaviour. The conclusions we can deduct from the study among other things are that: (i) organizational culture influence inter-group work behaviour in the organization. (ii) organizational culture is a determinant of the productivity level of the organization in the sense that it influences inter-group behaviour to work and it is the input of the employees to the organization that determines its productivity level. (iii) a change in organizational culture will lead to a change in inter-group behaviour in the sense that it is not what has been identified with the organization from time past. Therefore, organizations should make the changes in their culture easy for their employees to learn and adapt to. (iv) organizational culture has a significant influence on inter-group behaviour.

\section{RECOMMENDATIONS}

The following recommendations are made to the management of Guarantee Trust Bank;

(i) Every individual has different culture and beliefs that he works with and when he comes to an organization that has a completely different culture and beliefs from his own, he must be allow to internalize himself first with the organization's culture and beliefs to know whether he can cope with them or not. It is the ability of the employee to cope with the organizations culture that will determine how he behaves at work. It is strongly recommended that Guarantee Trust Bank should encourage new entrants to get internalize first with the organizations culture to know whether they can cope with them or not.

(ii) Adequate motivational factors must be put in place in the organization for workers because it improves inter-group living standard and thus gingers inter-group towards achieving higher productivity. It is strongly recommended that Guarantee Trust Bank Plc. should provide adequate motivational factors like housing 
allowance, car loan, holiday allowance, health allowance, etc. that will make their employee feel comfortable with themselves and their job and thus thrive towards higher productivity. Hardworking and productive employees should also be compensated as and when due.

(iii) When an organization culture is unstable and changes from time to time, it makes the inter-group discourage and tired of learning different culture all the time. It is strongly recommended that Guarantee Trust Bank Plc. should operate with a strong culture and not weak culture. It is a weak culture that changes from time to time. Strong cultures are cultures that are established by the founders of an organization to become the organizations way of life.

(iv) In cases where an organizational culture must be change, employees must first of all be notified and made to learn the modification of the old culture or otherwise the new culture. Organizations are recommended to always make their workers comfortable with their culture as this will reduce the rate of employee turnover.

(v) Finally, organizational culture of Guarantee Trust Bank Plc. must be binding on all members and staff of the company as this will encourage uniformity among members of the organization and thus enhance commitment and group efficiency.

\section{REFERENCES}

1. Bretz, R. D. and Judge, T. (1994). PersonOrganization Fit and the Theory of Work Adjustment: Implications for Satisfaction, Tenure, and Career Success. Journal of Vocational Behavior, 44: 32-54.

2. Buchanan, D. and Huczynski, A. (2004). Organizational Behaviour: An Introductory Text. (5th ed.). Essex: Prentice Hall Financial Times.

3. Cable, D. M. and Judge, T. A. (1996). PersonOrganization Fit, Job Choice Decisions, and Organizational Entry. Organizational Behavior and Human Decision Processes, 67(3): 294-311.

4. Cable, D. M. and Judge, T. A. (1997). Interviewers Perceptions of Person-Organization Fit and Organizational Selection Decisions. Journal of Applied Psychology, 82(4): 546-561.

5. Cascio, W. F. (2006). Managing Human Resources: Productivity, Quality of Life, Profits.7th Edition, Irwin: McGraw-Hill.

6. Deal, T. and Kennedy, A. (1999). The New Corporate Cultures: Revitalizing the Workplace After Downsizing, Mergers and Reengineering. Perseus.

7. Finegan, J. E. (2000). The Impact of Person and Organizational Values on Organizational Commitment. Journal of Occupational and Organizational Psychology, 73(2): 149-169.
8. Hall, R. (1999). Organizations: Structures, Processes and Outcomes. Eaglewood Cliffs, NJ: Prentice Hall.

9. Hallett, T. (2003). Symbolic Power and Organizational Culture, Sociological Theory, Vol. 21, No. 2. pp. 128-149.

10. Handy, C. (1993). Understanding Organizations. Penguin Business, 4th Edition. Hollinshead, G., Nicholls, P. and Tailby, S. (2003). Employee Relations.2nd Edition Eaglewood Cliffs, NJ: Financial Times Prentice Hall.

11. Jehn, K. A. (1994). Enhancing Effectiveness, An Investigation of Advantages and Disadvantages of Value-Based Intragroup Conflict. The International Journal of Conflict Management, 5(3): 223-238.

12. Jones, M. C., Cline, M. and Ryan, S. (2006). Exploring Knowledge Sharing in ERP Implementation: An Organizational Culture Framework. Decision Support Systems 41:2, 411434.

13. McShane, S. L. and von Glinow, M. A. (2008). Organizational Behaviour. 4th Edition, Irwin: McGraw-Hill.

14. Ojo, O. (2003). Fundamentals of Research Methods. Lagos: Standard Publications.

15. Ojo, O. (2008). organizational Culture and Performance: Empirical Investigation of Nigerian Insurance Companies, Manager Journal, No. 2, pp. 118-127.

16. Ojo, O. (2009). Impact Assessment of Corporate Culture on Employee Job Performance, Business Intelligence Journal, Vol. 2, No. 2, pp. 388-397.

17. Ojo, O. (2010). organizational Culture and Corporate Performance: Empirical Evidence from Nigeria, Journal of Business Systems, Governance and Ethics, Vol. 5, No. 2, pp.1-12.

18. Osland, J. S., Kold, D. A. and Rubin, I. M. (2001). Organizational Behaviour: An Experimental Approach. New Jersey: Upper Saddle River.

19. Pettinger, R. (2000). Mastering Organizational Behaviour. New York: Palgrave.

20. Ritchie, M. (2000). Organizational Culture: An Examination of Its Effect on the Internalization Process and Member Performance. South Carolina: Southern Business.

21. Scott, E. D. (2000a). Moral Values Fit: Do Applicants Really Care? Business Ethics, 4: 405435

22. Shani, A.B. and Lau, J. B. (2005) Behaviour in Organizations: An Experiential Approach (8th ed.), New York: McGraw-Hill Irwin.

23. Sorensen, J. B. (2002). The Strength of Corporate Culture and the Reliability of Firm Performance. Administrative Science Quarterly, Vol. 47, No. 1. pp.70-91. 